\title{
Pemanfaatan Limbah Cangkang Telur Sebagai Bahan Substitusi Semen Pada Beton
}

\author{
Agnes Sentani Klau*1, Frans Phengkarsa*2, Olan Jujun Sanggaria ${ }^{3}$ \\ *1 Mahasiswa Program Studi Teknik Sipil, Universitas Kristen Indonesia Paulus Makassar, \\ Indonesia agnessentani9625@gmail.com \\ *2,3 Dosen Program Studi Teknik Sipil, Universitas Kristen Indonesia Paulus Makassar, Indonesia ${ }^{2}$ \\ fphengkarsa@ hotmail.com *2 $^{2}$ dan olanjujun@gmail.com ${ }^{* 3}$
}

Corresponding Author: olanjujun@gmail.com

\begin{abstract}
Abstrak
Perkembangan teknologi dapat memberikan dampak positif dan dampak negatif terhadap kehidupan manusia sehari-hari. Dampak negatif yang paling umum terjadi adalah limbah yang dihasilkan dari setiap aktivitas manusia. sebagian besar limbah ini dibuang begitu saja ke alam tanpa pengolahan. Salah satu limbah yang paling umum ditemukan adalah limbah cangkang telur. Jumlah limbah cangkang telur terus meningkat, namum tidak dikelola dan tidak dimanfaatkan secara optimal sehingga limbah tersebut perlu diolah, seperti memanfaatkan limbah cangkang telur tersebut pada campuran beton. Penelitian ini bertujuan untuk mengetahui pengaruh pemanfaatan limbah cangkang telur sebagai bahan substitusi semen dengan variasi serbuk limbah cangkang telur sebesar 0\%, 4\%, $6 \%$ dan $8 \%$ terhadap kekuatan beton. Mutu rencana beton ( $\mathrm{f}^{\prime} \mathrm{c}$ ) pada penelitian ini yaitu $25 \mathrm{MPa}$. Dari hasil penelitian diperoleh nilai kuat tekan beton secara berturut-turut sebesar 27,351 MPa, 25,842 $\mathrm{MPa}, 23,201 \mathrm{MPa}$ dan 21,504 MPa, nilai kuat tarik belah beton secara berturut-turut sebesar 2,712 $\mathrm{MPa}, 2,499 \mathrm{MPa}, 2,264 \mathrm{MPa}$ dan 2,146 $\mathrm{MPa}$, nilai modulus elastisitas beton secara berturut-turut sebesar 21912,043 MPa, 17437,327 MPa, 14447,336 MPa dan 12290,684 MPa. Dari hasil penelitian ini diketahui bahwa beton yang menggunakan serbuk limbah cangkang telur sebagai bahan substitusi semen dengan variasi $0 \%$ dan $4 \%$ dapat memenuhi mutu rencana beton.
\end{abstract}

Kata kunci: serbuk cangkang telur, kuat tekan, kuat tarik belah, modulus elastisitas

\begin{abstract}
Technological developments can have positive and negative impacts on everyday human life. The most common negative impact is the waste generated from every human activity. Most of this waste is simply dumped into nature without treatment. One of the most common waste found is eggshell waste. The amount of eggshell waste continues to increase, but it is not managed and not used optimally so that the waste needs to be processed, such as utilizing the eggshell waste in a concrete mixture. This study aims to determine the effect of using eggshell waste as a cement substitution material with variations of eggshell waste powder of $0 \%, 4 \%, 6 \%$ and $8 \%$ on the strength of the concrete. The quality of the concrete plan $\left(f^{\prime} c\right)$ in this study is $25 \mathrm{MPa}$. From the results of the study, the compressive strength of concrete was 27.351 MPa, 25.842 MPa, 23.201 MPa and 21.504 MPa, the value of the split tensile strength of concrete was 2.712 MPa, 2.499 MPa, 2.264 MPa and 2.146 MPa, the value of the modulus of elasticity. concrete were 21912,043 MPa, 17437.327 MPa, 14447,336 MPa and 12290.684 MPa, respectively. From the results of this study, it is known that concrete using eggshell waste powder as a cement substitution material with variations of $0 \%$ and $4 \%$ can meet the quality of the concrete plan.
\end{abstract}

Keywords: egg shell powder, compressive strength, split tensile strength, modulus of elasticity 


\section{PENDAHULUAN}

Perkembangan teknologi yang semakin pesat membuat perkembangan dalam berbagai bidang juga ikut berkembang. Perkembangan tersebut dapat memberikan dampak positif dan dampak negatif terhadap kehidupan manusia sehari-hari. Dampak negatif yang paling umum terjadi adalah limbah yang dihasilkan dari setiap aktivitas manusia [1]. sebagian besar limbah ini dibuang begitu saja ke alam tanpa pengolahan. Salah satu limbah yang paling umum ditemukan adalah limbah cangkang telur.

Menurut data Direktorat Jenderal Peternakan dan Kesehatan Hewan, produksi telur di Indonesia pada tahun 2019 mencapai 396.115 ton per bulannya [2]. Produksi telur diperkirakan akan telur meningkat mengingat tingginya tingkat penggunaan telur sebagai bahan baku makanan.

Jumlah limbah cangkang telur terus meningkat, namum tidak dikelola dan tidak dimanfaatkan secara optimal sehingga limbah tersebut perlu diolah, seperti memanfaatkan limbah cangkang telur tersebut pada campuran beton.

Cangkang telur diketahui mengandung kalsium karbonat. Kalsium karbonat tersebut diketahui sebagai salah satu bahan penyusun semen portland. Dengan demikian, cangkang telur dapat dipertimbangkan sebagai bahan semen pada campuran beton.

Adapun tujuan dari penelitian ini adalah (1) Untuk mengetahui pengaruh penggunaan limbah cangkang telur sebagai bahan substitusi semen pada beton terhadap kekuatan beton. (2) Untuk mengetahui komposisi campuran yang baik dengan menggunakan limbah cangkang telur sebagai bahan substitusi semen pada beton terhadap kekuatan beton.

Menurut SNI 2847:2013, beton adalah hasil pencampuran dari semen portland atau semen hidrolis lainnya, agregat halus, agregat kasar dan air, dengan atau tanpa bahan campuran tambahan (admixture) [3].

Cangkang telur adalah lapisan terluar dari telur yang berfungsi melindungi semua bagian telur dari luka atau kerusakan. Menurut Stadelman dan Cotteril (1973), komposisi dari cangkang telur adalah 98,2\% kalsium karbonat, 0,9\% magnesium dan 0,9\% fosfor [4]. Menurut Butcher da Miles (1990), rata-rata cangkang telur mengandung $3 \%$ fosfor dan 3\% magnesium, kalium natrium, seng, amngan, besi dan tembaga [5].

Tabel 1. Komposisi Cangkang Telur

\begin{tabular}{cc}
\hline Nutrisi & $\begin{array}{c}\text { Cangkang Telur } \\
(\% \text { Berat })\end{array}$ \\
\hline Air & $29-35$ \\
\hline Protein & $1,4-4$ \\
\hline Lemak Murni & $0,10-0,20$ \\
\hline Abu & $89,9-91,1$ \\
\hline Kalsium & $35,1-36,4$ \\
\hline Kalsium Karbonat & 90,0 \\
\hline Fosfor & 0,12 \\
\hline Sodium & $0,15-0,17$ \\
\hline Magnesium & $0,37-0,40$ \\
\hline Potasium & $0,10-0,13$ \\
\hline Sulfur & $0,09-0,19$ \\
\hline Alanin & 0,45 \\
\hline Arginin & $0,56-0,57$ \\
\hline &
\end{tabular}

Adapun pengujian karakteristik beton yang dilakukan yaitu pengujian kuat tekan beton, berdasarkan SNI 1974:2011 kuat tekan beton adalah nilai dari besarnya beban dari gaya tekan yang dihasilkan oleh mesin tekan per satuan luas, yang menyebabkan benda uji hancur dibebani dengan gaya tersebut. Pengujian kuat tarik belah beton, berdasarkan SNI 2941:2014 kuat tarik belah beton adalah nilai yang diperoleh dari pengujian beton silinder yang ditekan pada sisi panjangnya. 
Pengujian modulus elastisitas beton merupakan pengujian untuk mengukur kekakuan atau daya tahan bahan terhadap deformasi yang ditentukan dari perubahan tegangan terhadap regangan dalam batas elastisnya.

Beberapa penelitian sejenis terdahulu yaitu Kuat tekan dan kuat tarik beton cenderung menurun pada substitusi serbuk cangkang telur 0\% - 10\% [6]. Pengaruh variasi penambahan abu sekam padi dan cangkang telur terhadap kuat tekan beton diperoleh nilai kuat tekan beton tertinggi pada beton dalam kondisi normal [7]. Pada pembuatan beton campuran abu cangkang telur, semakin banyak campuran abu cangkang telur maka semakin meningkatkan biaya pembuatan beton [8]. Hasil kuat tekan beton normal lebih besar dari beton campuran cangkang telur ayam [9]. Beton yang dibuat dengan mensubstitusi sebagian fungsi semen dengan abu cangkang telur dan abu sekam padi memenuhi persyaratan beton standar K-175 pada komposisi 5\% dan 10\% [10]. Semakin banyak kadar cangkang telur ayam yang digunakan akan mempercepat setting time, namun akan menurunkan \% flow atau workability adonan mortar [11]. Untuk mendapatkan nilai slump $75-100 \mathrm{~mm}$ pada setiap penambahan persentase serbuk cangkang telur perlu penambahan air (FAS-aktual) sehingga beton memiliki workability yang baik [12]. Bubuk cangkang telur ayam ras pada campuran beton berpori menghasilkan peningkatan nilai permeabilitas pada reduksi 2,5\% [13]. Pengaruh penambahan serbuk cangkang telur, abu sekam padi, serta bahan tambahan serat sabut kelapa di variasi $10 \%$ dengan variasi $15 \%$ terjadi kesamaan pada nilai kuat lentur sebesar 1,5 $\mathrm{MPa}$ [14]. Beton dengan material cangkang telur dapat dimanfaatkan untuk pengerjaan konstruksi struktural ataupun nonstruktural [15].

\section{METODOLOGI}

\section{Persiapan Bahan Penelitian}

a. Agregat kasar dan agregat halus yang digunakan berasal dari Sungai Jeneberang, Gowa, Sulawesi Selatan.

b. Semen yang digunakan adalah semen PCC produksi PT. Semen Tonasa.

c. Air yang digunakan berasal dari air sumur bor Laboratorium Struktur dan Bahan, Universitas Kristen Indonesia Paulus Makassar.

d. Limbah cangkang telur berasar dari Toko Kue Browcyl Makassar.

\section{Persiapan Alat Penelitian}
a. Timbangan neraca dan timbangan digital.
b. Oven.
c. Ayakan/saringan.
d. Mesin penggetar ayakan.
e. Kerucut terpancung.
f. Mesin pencampur bahan (mixer/molen).
g. Cetakan benda uji berbentuk silinder berdiameter $15 \mathrm{~cm}$ dan tinggi $30 \mathrm{~cm}$.
h. Bak perendaman.
i. Kerucut Abrams.
j. Mesin pengujian.
k. Alat pendukung lain.

\section{Pengujian Karakteristik Agregat}

Agregat yang akan digunakan untuk campuran beton diperiksa karakteristiknya sebelum digunakan untuk menjamin kualitas mutunya. Pengujian dilakukan berdasarkan standar pengujian yang telah ditetapkan.

4. Perencanaan Campuran (Mix Design) dean Metode American Concrete Institute/ACI

Perencanaan campuran beton bermaksud untuk memenuhi komposisi dan proporsi bahan-bahan penyusun beton agar proporsi campuran dapat memenuhi syarat teknis dan ekonomis. Metode ACI mensyaratkan 
suatu campuran beton dengan mempertimbangkan sisi ekonomisnya dengan memperhatikan ketersedian bahan-bahan di lapangan, kemudahan pekerjaan, serta keawetan kekuatan beton.

\section{Trial Mix}

Trial mix dilakukan untuk mengetahui apakah komposisi yang telah dirancang dapat memenuhi kuat tekan rencana (f'c), dengan menggunakan faktor 3 hari.

6. Identifikasi dan Pembuatan Benda Uji

Jenis benda uji yaitu berbentuk silinder ukuran diameter $15 \mathrm{~cm}$ dan tinggi $30 \mathrm{~cm}$ untuk pengujian kuat tekan, kuat tarik belah dan modulus elastisitas beton dengan jumlah benda uji sebanyak 48 sampel.

Prosedur pembuatan benda uji :

a. Menyiapkan alat dan bahan.

b. Mempersiapkan material sesuai komposisi hasil desain campuran.

c. Menyiapkan mesin pencampur yang sudah dibersihkan. Selanjutnya menuangkan agregat kasar, agregat halus, semen dan serbuk cangkang telur sebagai substitusi semen dan mengaduk hingga bahan tersebut tercampur secara merata.

d. Memasukkan air sedikit demi sedikit sesuai hasil takaran mix design.

e. Melakukan uji slump.

f. Apabila nilai slump telah memenuhi spesifikasi, selanjutnya menuangkan adukan beton ke dalam cetakan secara bertahap sebanyak 3 lapisan dengan masing-masing lapisan ditumbuk dengan tongkat pemadat (rojokan) sebanyak 25 kali.

g. Mendiamkan benda uji dalam cetakan.

h. Mengeluarkan beton yang telah kering dari cetakan, kemudian memasuki tahap perawatan benda uji yaitu perendaman.

7. Perawatan Benda Uji

Perawatan benda uji dilakukan berdasarkan SNI 2493:2011, dengan cara merendam benda uji yang telah dilepas dari cetakan dan telah diberi tanda di dalam bak perendaman sampai 3 hari sebelum waktu pengujian.

8. Pengujian Karakteristik Beton

Pengujian karakterisitik beton dilakukan setelah tahap perawatan/curing dilaksanakan.
a. Pengujian kuat tekan beton (SNI 1974:2011) dilakukan pada benda uji umur 7, 14 dan 28 hari.
b. Pengujian kuat tarik belah beton (SNI 2491:2014) dilakukan pada benda uji umur 28 hari.
c. Pengujian modulus elastisitas beton (ASTM C 469-02) dilakukan pada benda uji umur 28 hari.

\section{ANALISA DAN PEMBAHASAN}

\section{Hasil Pemeriksaan Karakteristik Material}

Tabel 1. Rekapitulasi Pemeriksaan Karakteristik Agregat Halus

\begin{tabular}{cccc}
\hline Karakteristik & Hasil & Interval SNI & Keterangan \\
\hline Kadar Air & $4,696 \%$ & $3,00 \%-5,00 \%$ & Memenuhi \\
\hline Kadar Organik & No. 2 & $<$ No. 3 & Memenuhi \\
\hline Kadar Lumpur & $2,20 \%$ & $0,20 \%-6,00 \%$ & Memenuhi \\
\hline Berat Jenis SSD & 2,510 & $1,60-3,20$ & Memenuhi \\
\hline Absorpsi (Penyerapan) & $1,317 \%$ & $0,20 \%-2,00 \%$ & Memenuhi \\
\hline Berat Volume Padat & $1611,67 \mathrm{~kg} / \mathrm{m} 3$ & $1400-1900 \mathrm{~kg} / \mathrm{m} 3$ & Memenuhi \\
\hline Berat Volume Gembur & $1476,67 \mathrm{~kg} / \mathrm{m} 3$ & $1400-1900 \mathrm{~kg} / \mathrm{m} 3$ & Memenuhi \\
\hline Modulus Kehalusan & 3,001 & $2,20-3,10$ & Memenuhi \\
\hline
\end{tabular}


Tabel 2. Rekapitulasi Pemeriksaan Karakteristik Agregat Kasar

\begin{tabular}{cccc}
\hline Karakteristik & Hasil & Interval SNI & Keterangan \\
\hline Kadar Air & $0,667 \%$ & $0,5 \%-2,0 \%$ & Memenuhi \\
\hline Kadar Lumpur & $0,72 \%$ & $0,20 \%-1,00 \%$ & Memenuhi \\
\hline Berat Jenis SSD & 2,619 & $1,60-3,20$ & Memenuhi \\
\hline Absorpsi (Penyerapan) & $1,585 \%$ & $0,20 \%-2,00 \%$ & Memenuhi \\
\hline Berat Volume Padat & $1757,14 \mathrm{~kg} / \mathrm{m} 3$ & $1400-1900 \mathrm{~kg} / \mathrm{m} 3$ & Memenuhi \\
\hline Berat Volume Gembur & $1620,71 \mathrm{~kg} / \mathrm{m} 3$ & $1400-1900 \mathrm{~kg} / \mathrm{m} 3$ & Memenuhi \\
\hline
\end{tabular}

Tabel 3. Rekapitulasi Pemeriksaan Karakteristik Bahan Pengikat

\begin{tabular}{cccc}
\hline Karakteristik & Hasil & Interval SNI & Keterangan \\
\hline Berat Jenis Semen & 3,176 & $3,00-3,20$ & Memenuhi \\
\hline Berat Jenis Serbuk Cangkang Telur & 2,309 & $3,00-3,20$ & Tidak Memenuhi \\
\hline
\end{tabular}

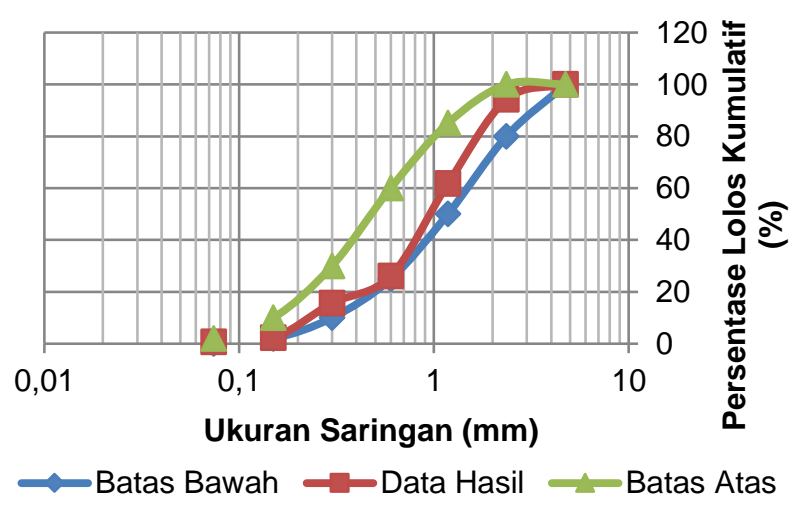

Gambar 1. Grafik Analisa Saringan Agregat Halus

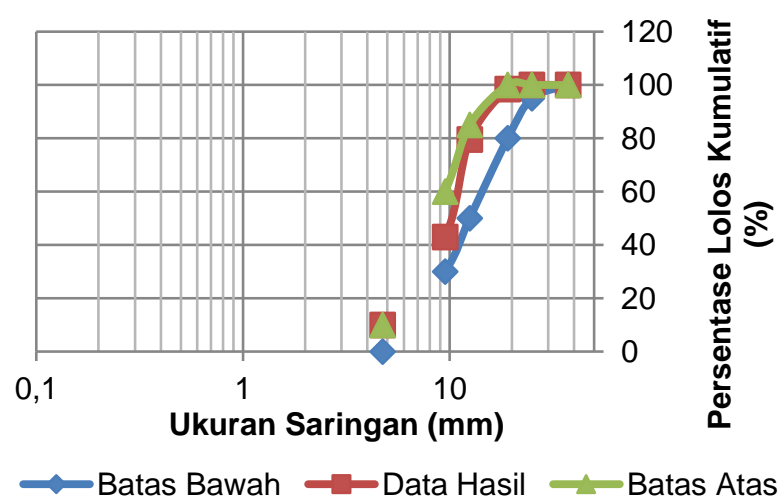

Gambar 2. Grafik Analisa Saringan Agregat Kasar 
Volume 3 Issue 4, Desember 2021

\section{Hasil Komposisi Mix Design}

Hasil komposisi mix design beton dengan mutu rencana $25 \mathrm{MPa}$ sebagai berikut :

Tabel 4. Komposisi Kebutuhan Bahan Campuran Beton untuk $1 \mathrm{~m}^{3}$

\begin{tabular}{cccccc}
\hline & \multicolumn{3}{c}{ Berat $\left(\mathbf{k g} / \mathbf{m}^{\mathbf{3}}\right)$} \\
\cline { 2 - 6 } $\begin{array}{c}\text { Substitusi Serbuk } \\
\text { Cangkang Telur }\end{array}$ & Semen & Air & Agregat Halus & Agregat Kasar & $\begin{array}{c}\text { Serbuk } \\
\text { Cangkang } \\
\text { Telur }\end{array}$ \\
\hline $0 \%$ & 470,732 & 184,085 & 601,088 & 1149,759 & - \\
\hline $4 \%$ & 451,903 & 184,085 & 601,088 & 1149,759 & 18,829 \\
\hline $6 \%$ & 442,488 & 184,085 & 601,088 & 1149,759 & 28,244 \\
\hline $8 \%$ & 433,073 & 184,085 & 601,088 & 1149,759 & 37,659 \\
\hline
\end{tabular}

\section{Hasil Pengujian Kuat Tekan Beton}

Pengujian dilakukan berdasarkan SNI 1974:2011 pada benda uji umur 7, 14 dan 28 hari dengan menggunakan Compression Testing Machine. Pengujian ini bertujuan untuk mengetahui kekuatan beton dalam menerima beban tekan dalam satuan $\mathrm{kN}$.

Tabel 5. Hasil Pengujian Kuat Tekan Beton

\begin{tabular}{|c|c|c|c|c|c|}
\hline \multirow[b]{2}{*}{ Variasi } & \multirow[b]{2}{*}{ Umur } & \multirow{2}{*}{$\begin{array}{c}\text { Kuat Tekan Beton } \\
\text { Aktual Rata-Rata } \\
\text { (MPa) }\end{array}$} & \multirow{2}{*}{$\begin{array}{c}\text { Kuat Tekan } \\
\text { Konversi } 28 \text { Hari } \\
\text { Rata-Rata } \\
(\mathrm{MPa}) \\
\end{array}$} & \multicolumn{2}{|c|}{ f'c } \\
\hline & & & & Min & $\operatorname{Max}$ \\
\hline $0 \%$ & \multirow{4}{*}{7 Hari } & 16,599 & 25,537 & 14,472 & 17,389 \\
\hline $4 \%$ & & 17,542 & 26,988 & 14,702 & 17,922 \\
\hline $6 \%$ & & 16,977 & 26,118 & 14,795 & 17,735 \\
\hline $8 \%$ & & 17,259 & 26,533 & 15,078 & 18,018 \\
\hline $0 \%$ & \multirow{4}{*}{14 Hari } & 23,579 & 26,794 & 21,086 & 24,158 \\
\hline $4 \%$ & & 23,013 & 26,151 & 20,520 & 23,592 \\
\hline $6 \%$ & & 22,164 & 25,186 & 19,671 & 22,743 \\
\hline $8 \%$ & & 21,315 & 24,222 & 18,822 & 21,894 \\
\hline $0 \%$ & \multirow{4}{*}{28 Hari } & 27,351 & 27,351 & 24,858 & 27,930 \\
\hline $4 \%$ & & 25,842 & 25,842 & 23,349 & 26,421 \\
\hline $6 \%$ & & 23,201 & 23,201 & 21,020 & 23,960 \\
\hline $8 \%$ & & 21,504 & 21,504 & 19,748 & 22,507 \\
\hline
\end{tabular}




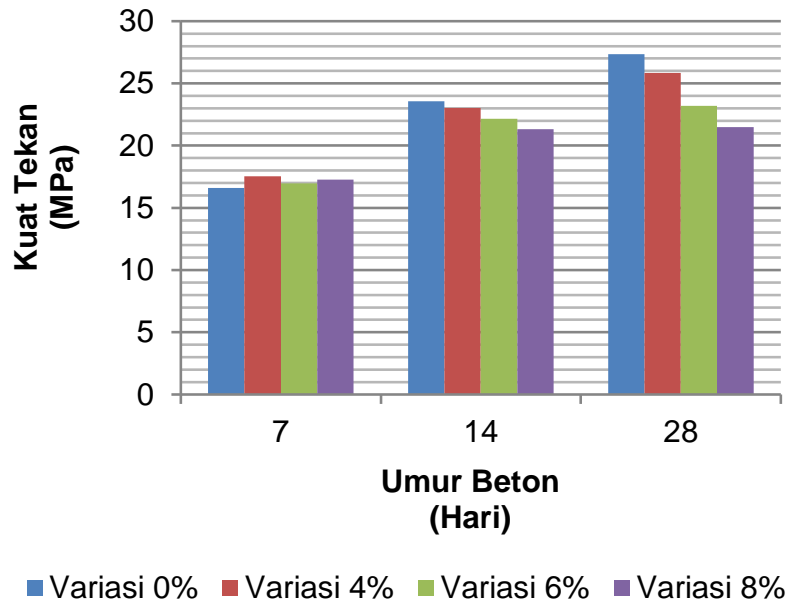

\section{Gambar 3. Hubungan Antara Umur Beton dengan Kuat Tekan Beton}

Berdasarkan gambar 3, dapat dilihat bahwa nilai kuat tekan untuk variasi $0 \%, 4 \%, 6 \%$ dan 8\% mengalami penurunan seiring bertambahnya umur rencana dan meningkatnya persentase variasinya. Hasil pengujian kuat tekan dengan kuat tekan rencana $25 \mathrm{MPa}$ pada variasi $0 \%, 4 \%, 6 \%$ dan $8 \%$ sebagai bahan substitusi semen pada umur 28 hari secara berturut-turut 27,351 MPa, 25,842 MPa, 23,201 MPa dan 21,504 MPa. Dimana nilai kuat tekan terbesar pada substitusi serbuk limbah cangkang telur sebesar 0\% yaitu 27,351 MPa.

\section{Hasil Pengujian Kuat Tarik Belah Beton}

Pengujian dilakukan berdasarkan SNI 2491:2014 pada benda uji umur 28 hari. Pengujian ini bertujuan untuk mengetahui berapa gaya tarik maksimum beton dalam satuan $\mathrm{kN}$.

Tabel 6. Hasil Pengujian Kuat Tarik Belah Beton

\begin{tabular}{cccc}
\hline $\begin{array}{c}\text { Variasi Serbuk } \\
\text { Cangkang Telur }\end{array}$ & $\begin{array}{c}\text { Beban Maksimum } \\
(\mathbf{k N})\end{array}$ & $\begin{array}{c}\text { Kuat Tarik Belah } \\
(\mathbf{M P a})\end{array}$ & $\begin{array}{c}\text { Kuat Tarik Belah Rata- } \\
\text { Rata } \\
(\mathbf{M P a})\end{array}$ \\
\hline \multirow{2}{*}{$0 \%$} & 200 & 2,829 & 2,712 \\
\cline { 2 - 4 } & 180 & 2,546 & 2,499 \\
\hline \multirow{2}{*}{$4 \%$} & 195 & 2,759 & 2,264 \\
\hline & 160 & 2,264 & 2,759 \\
\hline & 195 & 2,476 & 2,146 \\
\hline
\end{tabular}




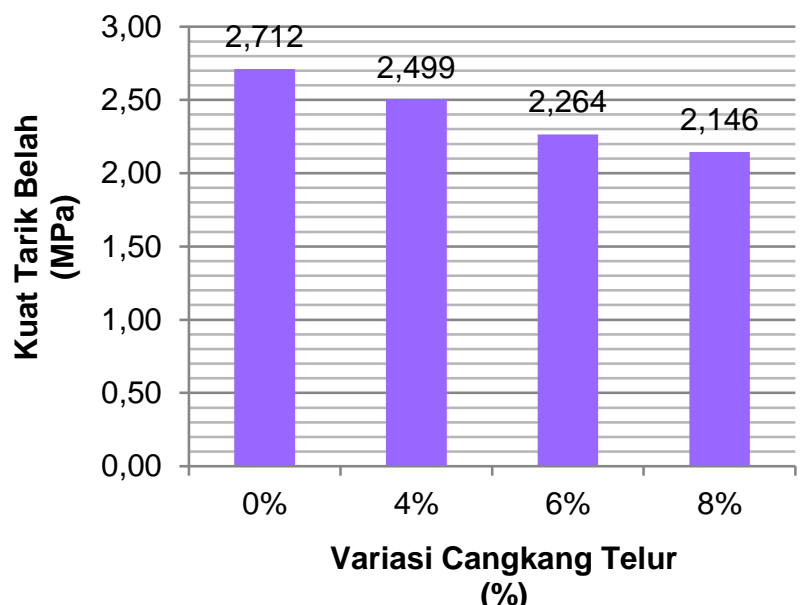

Gambar 4. Hubungan antara Variasi Serbuk Cangkang Telur dengan Kuat Tarik Belah Beton

Dari gambar 4 menunjukkan hubungan antara variasi substitusi serbuk cangkang telur dengan kuat tarik belah beton mengalami penurunan seiring dengan peningkatan variasi substitusi. Hasil pengujian kuat tarik belah pada variasi serbuk cangkang telur $0 \%, 4 \%, 6 \%$ dan $8 \%$ sebagai bahan substitusi semen secara berturut-turut sebesar 2,712 MPa, 2,499 MPa, 2,264 MPa dan 2,146 MPa. Dimana kuat tarik belah terbesar pada substitusi serbuk limbah cangkang telur sebesar $0 \%$ yaitu 2,712 MPa.

\section{Hasil Pengujian Modulus Elastisitas Beton}

Pengujian ini bertujuan untuk mengetahui besarnya beban yang dapat dipikul tanpa merusak beton itu sendiri (masih dalam keadaan plastis). Pengujian modulus elastisitas beton dilakukan pada beton umur 28 hari.

Tabel 7. Hasil Pengujian Modulus Elastisitas Beton

\begin{tabular}{|c|c|c|c|c|c|}
\hline Variasi & Kode Benda Uji & $\begin{array}{l}\text { Modulus } \\
\text { Elastisitas } \\
\text { (MPa) }\end{array}$ & $\begin{array}{c}\text { Modulus } \\
\text { Elastisitas Rata- } \\
\text { Rata } \\
\text { (MPa) }\end{array}$ & $\begin{array}{l}\text { Modulus } \\
\text { Elastisitas } \\
\text { Teoritis } \\
\left(4700 \sqrt{ } \mathbf{f}^{\prime} \mathbf{c}\right) \\
(\mathbf{M P a}) \\
\end{array}$ & $\begin{array}{c}\text { Modulus } \\
\text { Elastisitas } \\
\text { Teoritis Rata- } \\
\text { Rata } \\
(\mathbf{M P a}) \\
\end{array}$ \\
\hline \multirow{3}{*}{$0 \%$} & SCTKT A 28 (1) & 21397,483 & \multirow{3}{*}{21912,043} & 24622,522 & \multirow{3}{*}{24579,666} \\
\hline & SCTKT A 28 (2) & 21160,459 & & 24367,359 & \\
\hline & SCTKT A 28 (3) & 23178,187 & & 24749,116 & \\
\hline \multirow{3}{*}{$4 \%$} & SCTKT B 28 (1) & 16254,122 & \multirow{3}{*}{17437,327} & 23717,446 & \multirow{3}{*}{23891,929} \\
\hline & SCTKT B 28 (2) & 18681,067 & & 24109,496 & \\
\hline & SCTKT B 28 (3) & 17376,792 & & 23848,845 & \\
\hline \multirow{3}{*}{$6 \%$} & SCTKT C 28 (1) & 14423,080 & \multirow{3}{*}{14447,336} & 22638,810 & \multirow{3}{*}{22637,687} \\
\hline & SCTKT C 28 (2) & 13517,610 & & 22361,022 & \\
\hline & SCTKT C 28 (3) & 15401,320 & & 22913,229 & \\
\hline \multirow{3}{*}{$8 \%$} & SCTKT D $28(1)$ & 12473,890 & \multirow{3}{*}{12290,684} & 21506,143 & \multirow{3}{*}{21792,645} \\
\hline & SCTKT D 28 (2) & 11803,207 & & 21650,967 & \\
\hline & SCTKT D 28 (3) & 12594,956 & & 22220,826 & \\
\hline
\end{tabular}




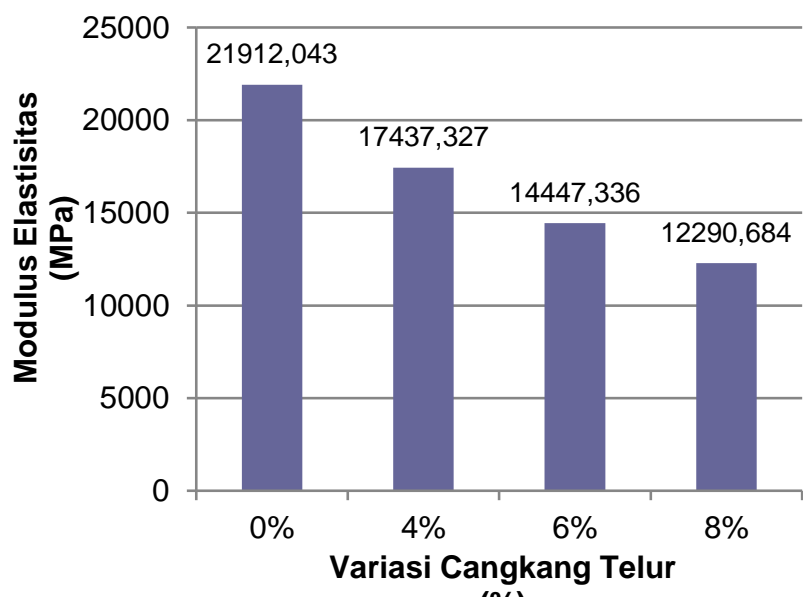

(\%)

\section{Gambar 5. Hubungan Variasi Serbuk Cangkang Telur Terhadap Modulus Elastisitas Beton}

Berdasarkan gambar 5, dapat diketahui hasil pengujian modulus elastisitas pada variasi serbuk cangkang telur 0\%, 4\%,6\% dan 8\% sebagai bahan substitusi semen secara berturut-turut sebesar 21912,043 MPa, 17437,327 MPa, 14447,336 MPa dan 12290,684 MPa. Dimana kuat tarik belah terbesar pada substitusi serbuk limbah cangkang telur sebesar 0\% yaitu 21912,043 MPa.

\section{KESIMPULAN}

Pengaruh kekuatan beton yang menggunakan serbuk limbah cangkang telur sebagai bahan substitusi semen dengan variasi $0 \%, 4 \%, 6 \%$ dan $8 \%$ diperoleh nilai kuat tekan yang memenuhi kuat tekan rencana $25 \mathrm{MPa}$ pada variasi $0 \%$ dan $4 \%$ yaitu sebesar 27,351 MPa dan 25,842 MPa, nilai kuat tarik belahnya sebesar 2,712 MPa dan 2,499 MPa dan nilai modulus elastisitasnya sebesar 21912,043 MPa dan 17437,372 MPa. Dari hasil penelitian ini, dapat diketahui bahwa serbuk cangkang telur dapat mempengaruhi kekuatan beton.

Komposisi campuran beton dengan menggunakan substitusi serbuk cangkang telur sebagai bahan substitusi semen diperoleh perbandingan semen, agregat halus dan agregat kasar sebesar $1: 1,28: 2,44$ dengan berat serbuk cangkang telur sesuai presentasi variasinya.

\section{DAFTAR PUSTAKA}

[1] L. D. R. K. Salle, "Pemanfaatan Limbah," in Pemanfaatan Material Alternatif (Sebagai Bahan Penyusun Konstruksi), Makassar, Tohar Media, 2021, pp. 59 - 67.

[2] Direktorat Jenderal Peternakan dan Kesehatan Hewan. 2019. "Statistik Peternakan dan Kesehatan Hewan 2019". Jakarta.

[3] Stadelman, W. J. and O. J. Cotterill. 1973. "Egg Science and Technology". The Avi Publishing Company, Inc.

[4] SNI 2847:2013.pdf. "Persyaratan Beton Struktural untuk Bangunan Gedung”. Accessed: Jan. 30, 2021. [Online]. Avaliable: http://staffnew.uny.ac.id/upload/132256207/pendidikan/sni-2847-2013.pdf.

[5] Butcher, G. D. and R. Miles. 1990. "Concepts of Eggshells Quality". http://edis.ifas.ufl.edu/pdffiles/VM/VM01300.PDF. (Accessed: Jan. 30, 2021)

[6] Y. F. Z. Dewi, H. Manalip, dan R. S. Windah. 2020. "Pengaruh Pnggunaan Serbuk Cangkang Telur Sebagai Substitusi Parsial Semen Terhadap Nilai Kuat Tarik Belah Beton”. Jurnal Sipil Statik, Vol. 8 No. 3, hlm 375 382.

[7] Julianti Siregar. 2016. "Pengaruh Variasi Penambahan Abu Sekam Padi Dan Cangkang Telur Terhadap Kuat Tekan Beton". Diploma Thesis, UNIMED.

[8] M. N. Abidin, Qomariah, dan A. Naibaho. 2020. 'Performa Beton Abu Cangkang Telur Sebagai Bahan Tambah Semen". JOS - MRK, Vol. 1 No. 2, hlm 164 - 169.

[9] D. Novianti, Syavira, Hamdi, dan L. F. Tilik. 2019. "Pengaruh Cangkang Telur Ayam Sebagai Substitusi Semen Terhadap Kuat Tekan Beton”. Pilar Jurnal Teknik Sipil, Vol. 14 No. 2, hlm 1 -6. 
[10] Hebron Pardede dan Mariana Surbakti. 2016. “Analisa Sifat Fisika dan Mekanik Beton Dengan Filler Abu Sekam Padi dan Cangkang Telor sebagai Pengganti Semen”. KULTURA, Vol. 17 No. 1, hal 5598 - 5603.

[11] G. A. Jaya Sasmita, M. R. Fernando, dan H. Sugiharto. 2019. "Pengaruh Substitusi Parsial Semen Dengan Cangkang Telur Ayam dan Fly Ash Pada Karakteristik Mortar Beton”. Jurnal Dimensi Pratama Teknik Sipil, Vol. 8 No. 1, hlm $79-86$.

[12] G. W. Y. Tumbel, S. O. Dapas, dan Mielke R. I. A. J. Mondoringin. 2020. 'Pengaruh Penggunaan Serbuk Cangkang Telur Sebagai Substitusi Parsial Semen Terhadap Nilai Kuat Tarik Lentur Beton”. Jurnal Sipil Statik, Vol. 8 No. 3, hlm 293 - 298.

[13] Frieda, O. Meilawaty, dan Fadia Aqila H. A. B. 2018. "Pemanfaatn Limbah Cangkang Telur Sebagai Pereduksi Semen Dalam Campuran Beton Berpori Ramah Lingkungan (Green Pervious Concrete). Jurnal Teknika, Vol. 1 No. 2, hlm $129-135$.

[14] F. V. Riza, D. S. Lubis, F. V. Br. Manurung, dan M. R, Rizaldi. 2020. “Analisis Mekanis Beton Busa Dengan Kombinasi Serat Sabut Kelapa Serta Bahan Tambahan Abu Sekam Padi Dan Serbuk Cangkang Telur”. PCEJ, Vol. 2 No. 1, hlm $53-67$.

[15] S. Fitriani, W. M. Fathul M, dan I. Farida. 2017. "Penggunaan Limbah Cangkang Telur, Abu Sekam dan Copper Slag Sebagai Material Tambahan Pengganti Semen”. Jurnal STT Garut, Vol. 15 No. 1, hlm 46 - 56. 